\title{
PENERAPAN MODEL DISCOVERY LEARNING PADA MATERI EKOSISTEM UNTUK MENINGKATKAN KEMAMPUAN BERPIKIR TINGKAT TINGGI SISWA KELAS X SMA
}

\author{
IMPLEMENTING OF DISCOVERY LEARNING MODEL ON \\ ECOSYSTEM SUBJECT TO IMPROVE HIGHER ORDER \\ THINKING SKILL STUDENTS AT CLASS X IPA OF SMA
}

\author{
BHIAN ANANDA JAVANICA RUBIYANTO*, MARJONO, BASKORO ADI PRAYITNO \\ Program Studi Pendidikan Biologi \\ Fakultas Keguruan dan Ilmu Pendidikan \\ Universitas Sebelas Maret \\ Jl. Ir. Sutami 36 A, Surakarta, 57126, Indonesia \\ *Corresponding Author: bhian.java93@gmail.com
}

Manuscript received : 11 Januari 2016 Revision accepted: 22 Maret 2016

\begin{abstract}
The research is aimed to improve higher order thinking skills students at class X IPA of SMA through the implementation of discovery learning model on the ecosystem subject. This research was a classroom action research which consists of two cycles. Each cycle contains four phases which were planning, acting, observing and reflecting. The subjects were students at class X IPA of SMA totaling 32 students. The data collecting techniques of this research were using test method obtained through essay test, and nontest method obtained through observation, interview, and documentation. The primary data is advanced higher order thinking skill of students with Bloom revised taxonomy to analyzing, evaluating, and creating measured using essays in accordance researchers any material indicators of ecosystem. The Data validate of this research were triangulation method. Analysis of data using qualitative descriptive analysis technique. The Target of research is to increase the higher order thinking skill's students $\geq 25$. The increase in higher order thinking skills results by the increasing student achievement of the average score of aspects of higher order thinking skills students were: 1)aspect analyzing of 52.66 with the moderate criteria of being at base line be 66.98 with the moderate criteria of being in the cycle I, then the the cycle II into 80,52 with a high criteria, 2)evaluating aspects of 45.83 with low criteria on base line be 64.17 with the moderate criteria of being in the cycle I, then on the cycle II into 73.96 with moderate criteria, and 3)creating aspects of 50,31 with the moderate criteria of being at base line be 68,49 with the moderate criteria of being in the cycle I, then on the cycle II into 76,35 with high criteria. Implication of discovery learning can increase the high order thinking skills students in base line, Cycle I and Cycle II. The score of test each aspect of higher order thinking skill aspect were: 1)analyzing increased by $27,86,2$ )evaluating an increase of 28,13 from, and 3)creating increased by 26,04 . This conclusion was implementation of discovery learning could improveas much as $\geq 25$ of high order thinking skills students at class X IPA of SMA.
\end{abstract}

Keywords : higher order thingking skill, discovery learning

\section{PENDAHULUAN}

Perkembangan industri, sains, dan teknologi yang pesat di abad 21 membawa konsekuensi besar bagi kehidupan manusia. Manusia dituntut untuk mampu beradaptasi dengan perubahan tersebut. Abad 21 dibutuhkan Sumber Daya Manusia (SDM) yang mampu memecahkan permasalahan secara efisien, mengevaluasi, menganalisis argumentasi, klaim dan bukti, serta melaksanakan permasalahan non rutin (Greenhill, 2010).

Kebutuhan terhadap tantangan abad 21 tersebut salah satunya adalah kemampuan berpikir, yakni kemampuan berpikir yang berada pada tingkat yang tinggi. Berpikir merupakan salah satu media penting yang memungkinkan manusia untuk mempersiapkan diri dalam menghadapi perubahan serta mengembangkan kemampuan berpikir adalah dengan pendidikan.

Kemampuan berpikir tingkat tinggi siswa menjadi penting untuk dikembangkan melalui pembelajaran sains khususnya biologi yang memiliki karakteristik pembelajaran yang mempelajari tentang fenomena alam yang membutuhkan kemampuan berpikir logis, analitis, sistematis, kritis, kreatif, serta kemampuan untuk memecahkan berbagai masalah.

Idealnya pembelajaran biologi diarahkan untuk melatih kemampuan berpikir tingkat tinggi melalui kegiatan menemukan konsep secara mandiri. Berdasarkan penelitian Burke, L, A., \& Williams, J, M., (2012) menunjukan bahwa proses berpikir dalam kegiatan pembelajaran mandiri 
BIO-PEDAGOGI 5(1): 6 - 14, April 2016

dapat meningkatkan kecerdasan dalam membangun konsep.

Kemampuan berpikir menurut Yaumi (2013) merupakan salah satu dari domain kognitif berdasarkan hierarki Bloom yang telah direvisi. Tingkatan kemampuan berpikir tersebut meliputi: (C1) remembering, (C2) understanding, (C3) applying, (C4) analyzing, (C5) evaluating, dan (C6) creating (Anderson \& Krathwohl, 2010). Kemampuan berpikir menurut Ramos, Dolipas, \& Villamor, (2013) dapat dibedakan menjadi dua, yakni berpikir tingkat rendah (low order thinking skill) dan berpikir tingkat tinggi (higher order thinking skill).

Berdasarkan hasil observasi secara umum di kelas X IPA SMA menunjukkan bahwa proses pembelajaran bersifat transfer knowledge atau bersifat satu arah yang mengakibatkan respon siswa cenderung untuk pasif belajar. Aktivitas siswa hanya mencatat materi dan mendengarkan apa yang disampaikan oleh guru dengan bantuan media power point mengakibatkan siswa tidak terlibat dalam melakukan kegiatan berpikir. Dua pertiga dari alokasi waktu pembelajaran dihabiskan oleh guru untuk menjelaskan materi, dan siswa hanya diberi sedikit kesempatan untuk mengemukakan pendapatnya.

Menurut Ahmadi, (2014) bahwa pembelajaran dengan metode ceramah mengakibatkan siswa menjadi pasif belajar, pembelajaran menjadi membosankan dan kurang mengembangkan daya kritis siswa. Yunginger, (2008) menambahkan bahwa banyaknya siswa yang mencatat dan mendengarkan menunjukkan oral activity yang kurang terlatih.

Pada akhir pembelajaran guru kurang memberi waktu pada siswa untuk menanggapi dan menyusun pertanyaan sehingga interaksi selama proses pembelajaran didominasi oleh guru dan hanya $12,5 \%$ siswa yang aktif bertanya dengan pertanyaan yang berupa $\mathrm{C} 1$ dan $\mathrm{C} 2$. Pendapat Deluty (2010) diperkuat oleh pernyataan Walsh dan Sattes, (2011) bahwa pertanyaan yang diajukan siswa merupakan tanda keterlibatan siswa dalam belajar dan berpikir. Observasi juga dilakukan pada tipe soal ulangan harian yang menunjukkan soal masih bertipe $\mathrm{C} 1$ sampai $\mathrm{C} 3$.

Hasil observasi menunjukkan pembelajaran kurang melatihkan kemampuan berpikir, hal ini didukung oleh pendapat Art-in (2012) bahwa pembelajaran yang fokus pada proses berpikir, yakni pembelajaran yang melibatkan pertanyaan sehingga merangsang siswa. Selain itu, kemampuan berpikir juga dilatihkan melalui pembelajaran yang menekankan pada aktivitas siswa dalam mencari pemahaman suatu objek, menganalisis dan mengkonstruksinya untuk membentuk pengetahuan baru dalam diri individu.
Hasil observasi diperkuat dengan memberikan tes essay pada tanggal 24 Maret 2016 berdasarkan aspek kemampuan berpikir tingkat tinggi berjumlah 6 butir soal yang mencakup aspek kemampuan berpikir C4 (analyzing), C5 (evaluating), dan C6 (creating). Hasil tes menunjukkan bahwa nilai rata-rata siswa pada aspek analyzing sebesar 52,66 dengan kriteria sedang, aspek evaluating sebesar 45,83 dengan kriteria rendah, dan creating sebesar 50,31 dengan kriteria sedang. Hasil nilai rata-rata capaian kelas sesuai dengan hasil observasi yang menunjukan bahwa kemampuan berpikir tingkat tinggi siswa kelas X IPA SMA termasuk dalam kriteria nilai yang berada antara 40 sampai 50, yakni dengan kriteria kurang.

Berdasarkan hasil diskusi antara peneliti, guru biologi, dan pembimbing diputuskan untuk segera menyelesaikan satu masalah yang dianggap penting dari persentase gejala yang diamati paling besar. Masalah yang dipilih yaitu rendahnya kemampuan berpikir tingkat tinggi siswa. Alasan pentingnya mengatasi masalah tersebut karena berpikir kemampuan berpikir tingkat tinggi merupakan salah satu faktor penting dalam melatih kecerdasan kognisi siswa yang dapat mempengaruhi pencapaian prestasi belajar. Diperkuat oleh penyataan Chatib (2012) yang menyatakan bahwa kemampuan kognisi siswa yang berada pada kemampuan berpikir tingkat tinggi berguna untuk hasil berpikir yang berkualitas dalam memahami informasi.

Peningkatan kemampuan berpikir tingkat tinggi siswa dapat diupayakan melalui model pembelajaran yang mengakomodasi dan meningkatkan aktivitas kognitif siswa. Sesuai dengan pendapat Barak, Ben Chaim \& Zoller, (2007) bahwa pembelajaran yang bersifat konstruktivisme menekankan kebutuhan siswa belajar melalui pengalaman untuk membangun konsep dan mengembangkan kemampuan berpikir tingkat tinggi. Salah satu model pembelajaran yang sesuai dengan teori konstruktivisme dan melatih kemampuan berpikir tingkat tinggi yaitu model pembelajaran discovery learning. Menurut Klahr \& Nigam, (2004) discovery learning merupakan pembelajaran konstruktivis yang dilakukan dengan mengkonstruksi fenomena-fenomena, melalui penyelidikan berdasarkan prosedur ilmiah untuk menemukan suatu pemahaman yang luas mengenai fenomena yang disajikan dalam pembelajaran.

Discovery learning terdiri dari sintaks orientation, hypothesis generation, hyphotesis testing, conclusion, dan regulation (Veermans, 2003). Orientation adalah proses membimbing siswa untuk membangun ide awal dari materi pembelajaran yang dilakukan melalui kegiatan membaca, mengeksplorasi, mengidentifikasi variabel materi serta menghubungkan pengetahuan 
yang diperoleh terhadap masalah yang dihadapi. Sintaks orientation dilakukan memberikan simulasi kepada siswa yang kemudian siswa diarahkan untuk mengidentifikasi masalah berdasarkan simulasi yang dihadapinya. Menurut Kowalski \& Kowalski, (2013) bahwa simulasi dapat mendorong rasa ingin tahu siswa.

Hypotesis generation adalah proses menyusun hipotesis atau jawaban sementara dari masalah yang disajikan. Prediksi bertujuan untuk menganalisis solusi atau perkiraan yang efektif dalam memecahkan masalah (Burns, Leppien, Omdal, Gubbins, Muller \& Vahidi, 2006). Hypotesis testing adalah kegiatan pengujian kebenaran hipotesis yang dilakukan dengan cara merancang eksperimen, mengamati, mengumpulkan data, menginterpretasikan hasil pembelajaran. Proses penemuan pada kegiatan hypothesis testing diiringi kegiatan menganalisis, mengevaluasi, dan mencipta. Conclusion adalah kegiatan pengambilan kesimpulan berdasarkan hasil penemuan. Siswa akan menyimpulkan apakah (bukti) hasil eksperimen yang dilakukan sesuai dengan hipotesis ataukah terjadi perbedaan antara hasil eksperimen dengan hipotesis. Mengidentifikasi perbedaan (comparing) antara hasil eksperimen dan hipotesis merupakan kemampuan dasar yang melatih siswa untuk berpikir kompleks (Burns, et al., 2006). Regulation adalah proses evaluasi yang dilakukan siswa untuk mengelola perubahan yang diperoleh siswa setelah kegiatan pembelajaran. Evaluasi adalah suatu proses yang sistematis dan berkelanjutan untuk menentukan kualitas suatu objek berdasarkan pertimbangan dan kriteria tertentu dalam rangka pembuatan kesimpulan (Arifin, 2009).

Discovery learning memiliki karakteristik masalah yang dihadirkan harus berdasarkan fenomena nyata dalam kehidupan sehari-hari (Akinoglu \& Tandogan, 2007). Materi yang cocok untuk memenuhi kriteria pembelajaran discovery learning adalah Ekosistem karena karakteristik materi pada ekosistem membahas mengenai lingkungan dengan menghadirkan berbagai fenomena nyata yang sangat erat kaitannya dengan kehidupan sehari-hari manusia.

Discovery learning sebagai alternatif pembelajaran yang mengakomodasi dan melatih kemampuan berpikir tingkat tinggi siswa di kelas yang menempatkan aspek berpikir tingkat tinggi seperti: menganalisis, mengevaluasi, dan mencipta sebagai bagian penting pada setiap sintaks kegiatannya. Berdasarkan latar belakang di atas maka perlu dilakukan penelitian dengan judul: "Penerapan Model Discovery Learning pada Materi Ekosistem untuk Meningkatkan Kemampuan Berpikir Tingkat Tinggi Siswa Kelas X IPA SMA".

Tujuan penelitian ini adalah untuk meningkatkan kemampuan berpikir tingkat tinggi siswa kelas X IPA SMA melalui penerapan model discovery learning pada materi ekosistem. Hasil penelitian diharapkan dapat memberikan gambaran yang jelas pada guru tentang model discovery learning pada materi ekosistem sehingga mampu diimplementasikan dengan optimal dan meningkatkan kemampuan berpikir tingkat tinggi siswa.

\section{METODE PENELITIAN}

Penelitian ini akan dilaksanakan di kelas $\mathrm{X}$ IPA Semester II SMA Negeri di Surakarta. SMA ini terletak di Jalan Muhamad Yamin No. 79 Kota Surakarta 57154. Telepon dan fax (0271) 718679. SMA ini terletak tepat di pinggir jalan raya. Sekolah ini menghadap ke arah utara, yakni menghadap jalan kecil, di sebelah kiri atau barat SMA ini terdapat selokan besar, sedangkan di belakang atau sebelah timur SMA merupakan pemukiman warga. Pelaksanaan penelitian dilakukan secara bertahap, secara garis besar dapat dibagi menjadi tiga tahap yakni tahap persiapan, pelaksanaan, dan penyusunan laporan. Metode penelitian yang digunakan adalah Penelitian Tindakan Kelas (PTK), terdiri dari 4 tahapan dasar yang saling terkait dan berkesinambungan, yaitu perencanaan (planning), pelaksanaan (acting), pengamatan (observing) dan refleksi (reflecting). Penelitian ini menerapkan model learning cycle $5 E$ untuk mengetahui peningkatan partisipasi aktif siswa. Tindakan berlangsung pada semua siklus (minimal 2 siklus) pada materi Ekosistem hingga target peningkatan partisipasi aktif tercapai. Observasi awal dilakukan untuk mengetahui kondisi awal proses pembelajaran. Penelitian ini bertujuan untuk memecahkan masalah yang timbul dalam kelas. Penelitian dilaksanakan dengan berkolaborasi bersama guru bidang studi.

Data yang dikumpulkan berupa data primer dan sekunder. Data primer yang dikumpulkan merupakan hasil berupa kemampuan berpikir tingkat tinggi siswa yang diukur melalui tes soal berpikir tingkat tinggi yang melingkupi aspek kemampuan berpikir C4 (analyzing), C5 (evaluating), dan C6 (creating) dengan menggunakan soal essay yang dipecah menjadi 8 kategori kognitif, yakni: membedakan, mengorganisasikan, mengatribusi, memeriksa, mengkritik, merumuskan, merencanakan dan memproduksi. Data sekunder meliputi observasi keterlaksanaan sintaks model discovery learning secara langsung dengan menggunakan lembar observasi, wawancara sebagai klarifikasi pertanyaan yang dilakukan oleh peneliti kepada siswa dan guru serta dokumentasi berupa rekaman video selama proses pembelajaran atau arsip yang mendukung penelitian. 
BIO-PEDAGOGI 5(1): 6 - 14, April 2016

Teknik yang digunakan untuk mengumpulkan data penelitian meliputi: tes, observasi, wawancara, dan dokumentasi. Teknik analisis yang digunakan adalah deskriptif kualitatif berdasarkan hasil observasi dan refleksi dari tiap siklus. Prosedur dan langkah-langkah dalam penelitian tindakan kelas ini mengikuti model yang dikembangkan oleh Kemmis dan Mc Taggart, (2005) berupa model spiral yaitu dalam satu siklus terdiri dari tahap perencanaan, tindakan, observasi dan refleksi.

\section{HASIL DAN PEMBAHASAN}

Hasil penelitan ditampilkan pada Tabel dan gambar di bawah ini:

Tabel 1. Perbandingan Nilai Rata-rata Kemampuan berpikir tingkat tinggi siswa pada Pratindakan, Siklus I dan Siklus II.

\begin{tabular}{lccccc}
\hline \multirow{2}{*}{ Aspek } & $\begin{array}{c}\text { Base } \\
\text { line }\end{array}$ & $\begin{array}{c}\text { Siklus } \\
\text { I }\end{array}$ & $\begin{array}{c}\text { Siklus } \\
\text { II }\end{array}$ & $\begin{array}{c}\text { Kenaikan } \\
\text { Nilai }\end{array}$ & Ket. \\
\hline Menganalisis & 52,66 & 66,98 & 80,52 & 27,86 & Tercapai \\
Mengevaluasi & 45,83 & 64,17 & 73,96 & 28,13 & Tercapai \\
Mencipta & 50,31 & 68,49 & 76,35 & 26,04 & Tercapai \\
\hline
\end{tabular}

Berdasarkan Tabel 1. Dapat diketahui bahwa terdapat peningkatan hasil tes kemampuan berpikir tingkat tinggi siswa melalui model discovery learning dari pratindakan, siklus I, dan siklus II. Peningkatan terjadi pada setiap aspek kemampuan berpikir tingkat tinggi. Aspek menganalisis meningkat 27,86 dari base line, aspek mengevaluasi meningkat 28,13 dari base line, dan aspek mencipta meningkat 26,04 dari base line.

Berdasarkan Tabel 1. dapat dilihat peningkatan yang terjadi antara pratindakan menuju siklus I. Peningkatan tersebut dapat terjadi akibat adanya perlakuan berupa pembelajaran Biologi dengan model discovery learning. Sedangkan peningkatan pada siklus I menuju siklus II terjadi akibat refleksi perbaikan yang dilakukan pada siklus sebelumnya. Dapat terlihat pula aspek dari kemampuan menganalisis pada siklus II memiliki jumlah yang tertinggi, yakni 80,52, kemudian diikuti kemampuan mencipta 76,35, dan kemampuan mengevaluasi 73,96. Perbandingan pencapaian nilai kemampuan berpikir tinggi siswa masing-masing aspek menganalisis, mengevaluasi dan mencipta pada pratindakan, siklus I, dan siklus II dapat dilihat pada Gambar 1. sebagai berikut:

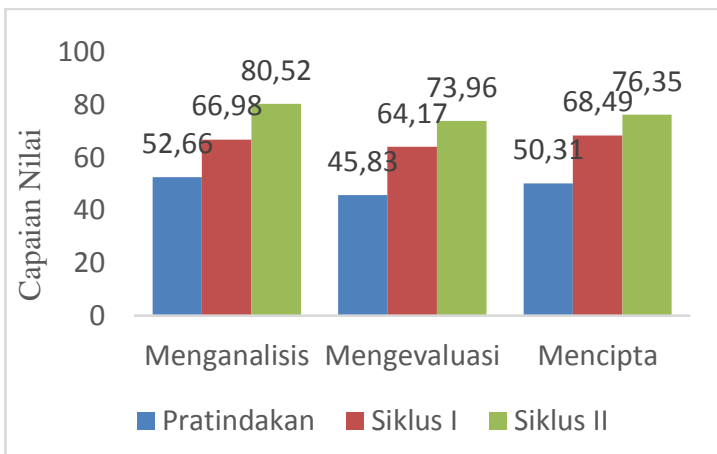

Gambar 1. Perbandingan Capaian Nilai Kemampuan Berpikir Tingkat Tinggi Siswa tiap Aspek pada Pratindakan, Siklus I, dan Siklus II.

Peningkatan kemampuan berpikir tingkat tinggi siswa tersebut juga didukung oleh peningkatan hasil wawancara dengan guru dan siswa, juga pengamatan yang dilakukan oleh observer. Berdasarkan hasil observasi proses pembelajaran terjadi peningkatan aspek kemampuan berpikir tingkat tinggi pada setiap sintaks discovery learning. Hal ini dikarenakan siswa sudah terbiasa untuk merumuskan masalah, mengajukan hipotesis, menguji hipotesis, dan melakukan studi literatur sendiri sehingga mereka dapat mengenali bukti, menjawab hipotesis, dan menarik kesimpulan dengan menggunakan pertimbangan induktif atau deduktif.

Hasil wawancara menunjukan pendapat siswa yang mengalami kemajuan dalam cara menyampaikan pendapat, memahami materi pembelajaran di kelas, aktif mengikuti kegiatan pembelajaran, dapat berbagi pendapat kepada teman sekelas, berani untuk mengajukan pertanyaan/ide/gagasan, dan meningkatkan nilai Biologi siswa. Kemajuan siswa tersebut menunjukan telah berjalannya kemampuan berpikir siswa yang salah satunya adalah kemampuan berpikir tingkat tinggi siswa, yakni pada aspek menganalisis, mengevaluasi dan mencipta.

Penerapan Model Discovery Learning pada penelitian ini telah mampu meningkatkan kemampuan berpikir tingkat tinggi siswa pada setiap aspek. Peningkatan tersebut meliputi aspek menganalisis, mengevaluasi, dan mencipta hingga $\geq 25$ dari profil awal siswa. Kemampuan berpikir tingkat tinggi merupakan kemampuan yang sangat penting dalam proses pendidikan, karena kemampuan berpikir tingkat tinggi dapat mempengaruhi siswa kecepatan dan efektivitas siswa belajar (Heong, et al., 2011). Berpikir tingkat tinggi dimaksudkan sebagai kemampuan berpikir untuk menganalisis, berpikir kritis, berpikir kreatif, dan memecahkan masalah sehingga dapat membuat keputusan yang masuk akal mengenai apa yang akan dikerjakan (Ramos, et al., 2013). Kemampuan berpikir tingkat tinggi siswa didapatkan dari kegiatan aktif mengkonstruk 
suatu informasi, yakni mengkaitkan konsep yang telah dipelajari dengan kegiatan yang ditemuinya sehari-hari melalui pengamatan, penyelidikan, pekerjaan rumah yang menyajikan berbagai kesempatan untuk berpikir, dan tes yang dirancang untuk mengembangkan kemampuan berpikir tingkat tinggi. Hasil observasi tindakan menunjukkan siswa menjadi lebih aktif dalam mencari sumber informasi untuk belajar, bertanya, mengeluarkan ide-ide, dan berpikir. Hal ini terjadi karena kegiatan diskusi siswa baik secara langsung maupun tidak langsung menjadi lebih interaktif dan mendalam. Salter, \& Conneely, (2015) mengatakan bahwa pembelajaran yang di dalamnya terdapat kegiatan untuk berdiskusi dapat memberdayakan siswa menjadi lebih aktif, dan responsif mengikuti pembelajaran.

Model discovery learning merupakan model pembelajaran yang membantu siswa menemukan pengetahuan yang dirumuskan dan mendorong kemampuan berpikir siswa menggunakan kemampuan berpikir secara analitis, evaluatif dan kreatif dalam mencipta. Model discovery learning memfasilitasi siswa untuk melatih kemampuan berpikir tingkat tinggi. Hal ini sesuai dengan penelitian Meyer (2010) yang menunjukkan bahwa proses penemuan (discovery) dalam pembelajaran akan membantu siswa memahami dan menganalisis proses kreativitas dan pengambilan keputusan pada temuannya. Penggunaan model discovery learning pada pembelajaran Biologi sebaiknya siswa diberikan porsi belajar yang lebih untuk mencari jawabannya, karena pada dasarnya model discovery learning didefinisikan sebagai proses pembelajaran yang terjadi bila siswa tidak disajikan dengan pelajaran dalam bentuk finalnya, tetapi diharapkan siswa mengorganisasi sendiri kegiatan belajar yang dilakukannya sehingga siswa mampu menemukan konsep atau jawaban atas permasalahan yang dihadapinya selama proses pembelajaran. Model discovery learning memiliki rangkaian kegiatan belajar yang melibatkan secara maksimal seluruh kemampuan berpikir siswa untuk mencari dan menyelidiki secara sistematis, logis, kritis, analitis.

Sintaks pada model discovery learning menempatkan aspek berpikir tingkat tinggi yang terwujud dalam kegiatan menganalisis, mengevaluasi dan mencipta sebagai bagian penting pada setiap sintaks kegiatannya. Proses pembelajaran yang dilakukan siswa dalam discovery learning menurut Veermans (2003) meliputi 5 sintaks, yaitu: orientation, hypothesis generation, hypothesis testing, conclusion, dan regulation. Sintaks orientation proses membimbing siswa untuk membangun ide awal dari materi pembelajaran. Menurut Barak, et al.,(2007) menyatakan bahwa pembelajaran dengan membangun pengetahuan siswa merupakan pembelajaran yang bersifat konstruktivisme yang dapat meningkatkan kemampuan berpikir tingkat tinggi salah satunya adalah kemampuan berpikir analitisnya. Siswa disajikan fenomena ekosistem yang ada di kelas kemudian guru meminta siswa untuk mengidentifikasi masalah yang ditampilkan. Menurut Zane (2013) mengidentifikasi merupakan subskill dari kemampuan menganalisis. Semua siswa memperhatikan gambar yang disajikan dan antusias dalam menyebutkan perbedaaan serta persamaan dari gambar-gambar. Semua peserta didik memperhatikan gambar yang disajikan dan antusias dalam menyebutkan perbedaaan serta persamaan dari gambar-gambar. Hasil tanggapan ditulis dalam papan tulis untuk dihubungkan dan disusun pertanyaan sebagai bahan untuk diskusi.

Sintaks orientation merupakan proses membimbing siswa untuk membangun ide awal dari materi pembelajaran yang dilakukan melalui kegiatan membaca, mengekplorasi, mengidentifikasi variabel materi serta menghubungkan pengetahuan yang diperoleh terhadap masalah yang dihadapi. Kegiatan orientasi pembelajaran dapat memberikan dampak rasa ingin tahu siswa terhadap masalah yang ditemuinya. Rasa ingin tahu siswa tersebut merupakan respon belajar aktif siswa. Pernyataan ini diperkuat oleh Litman (2005) bahwa rasa ingin tahu adalah keinginan untuk mengetahui sesuatu, dorongan untuk mencari pengalaman, dan memperoleh informasi mengenai pengetahuan, sehingga diperlukan dorongan untuk membuat siswa menjadi aktif.

Sintaks hypothesis generation, yaitu kegiatan penyusunan hipotesis dari masalah yang dibentuk. Pada siklus I dan siklus II siswa secara berkelompok menyusun hipotesis berdasarkan pengetahuan yang diketahui siswa dan kajian literatur. Berdasarkan proses yang dilakukan pada kegiatan ini siswa dilatih untuk meningkatkan aspek analyzing \& creating. Aspek analisis yang dilakukan siswa pada sintaks ini, yakni memilah informasi yang relevan untuk menjawab hipotesis dan menghubungkan antara informasi satu dengan yang lain yang diperoleh siswa sehingga tersusun jawaban yang koheren atau berkesinambungan. Pembentukan hipotesis tidak terlepas dari kemampuan berpikir mencipta siswa. Proses menciptakan gagasan terjadi melalui restrukturisasi dan berhubungan pengetahuan dan pengalaman dalam cara yang baru. Heong, dkk. (2012) mengatakan bahwa membentuk ide dengan menciptakan gagasan merupakan indikasi jelas dari proses berpikir.

Sintaks hypothesis testing, yaitu kegiatan pengujian kebenaran hipotesis yang dilakukan dengan cara mengumpulkan informasi dari berbagai sumber dengan panduan Lembar Kerja Siswa (LKS). Pada siklus I dan siklus II siswa aktif 
BIO-PEDAGOGI 5(1): 6 - 14, April 2016

bertanya dan menganalisis data yang diperoleh. Aspek kemampuan berpikir tingkat tinggi yang muncul dalam sintaks ini, yakni analyzing, evaluating, dan creating. Analisis yang dilakukan siswa dalam memilah informasi yang relevan dalam menjawab pertanyaan-pertanyaan diskusi, kemudian menghubungkan informasi-informasi yang diperoleh sehingga membentuk informasi yang berkesinambungan serta upaya masingmasing siswa untuk berpendapat dalam menyumbangkan solusi LKS. Siswa secara berkelompok akan saling mengevaluasi, yakni memeriksa jawaban dengan memanfaatkan sumber belajar lain seperti internet sehingga membantu dalam memahami solusi yang didiskusikan. Jawaban dalam satu kelompok dapat berbeda-beda, namun siswa selalu mencari sumber referensi yang relevan dan terpercaya guna mengetahui mana jawaban yang tepat. Penggunaan diskusi dapat mengembangkan berbagai keterampilan diri siswa seperti keterampilan berpikir, bertanya, berkomunikasi, menafsirkan dan menyimpulkan bahasan (Sumantri \& Permana, 2001).

Sintaks conclusion, yaitu kegiatan pembandingan antara hasil diskusi dengan hipotesis yang telah disusun. Pada siklus I dan siklus II siswa secara berkelompok mendiskusikan kesimpulan akhir dari rumusan masalah yang diperoleh. Pada siklus I siswa mengalami kesulitan dalam menyusun kesimpulan karena belum memahami cara penyusunan kesimpulan yang benar. Pada siklus II siswa dapat menyusun kesimpulan dengan bantuan bimbingan dari guru. Aspek yang dilatihkan dalam sintaks ini, yaitu aspek analyzing. Aspek menganalisis dilakukan dengan memilah hasil diskusi yang relevan sesuai dengan rumusan masalah dan membandingkannya dengan hipotesis untuk disusun kesimpulan yang benar kemudian siswa memberi pendapat mengenai kesimpulan yang sesuai.

Sintaks regulation merupakan kegiatan pengelolaan hasil pembelajaran yang telah dilakukan. Pada siklus I dan siklus II dilakukan dengan membimbing siswa menyimpulkan hasil pembelajaran yang diperoleh, melakukan tanyajawab dari hasil penemuan yang perlu diperjelas dan review dari guru untuk melengkapi pengetahuan dan membenarkan konsep siswa yang salah. Pada sintkas regulation dilakukan juga evaluating yang bersifat diagnostik dengan menyelesaikan tes uraian untuk mengetahui kemampuan kognitif siswa sebagai perbaikan pelajaran selanjutnya. Aspek yang dilatihkan dalam sintaks ini, yaitu aspek analyzing, yakni saling bertukar pendapat berdasarkan sudut pandang masing-masing siswa terhadap pembelajaran yang telah diperoleh.
Kompetensi yang didapatkan dari
kemampuan berpikir
analitis adalah mengidentifikasi dan mengklasifikasikan aspek yang berbeda dari sebuah objek, cerita, atau kejadian menjadi bagian-bagian kecil, dan menemukan hubungan antarkomponen yang saling terkait (Sitthipon, A., 2012). Siswa mulai dilatihkan kemampuan menganalisis pada setiap sintaks discovery learning, yakni dengan melakukan pengamatan, kemudian mengumpulkan data dengan mengerjakan Lembar Kerja Siswa (LKS) tentang komponen-komponen penyusun ekosistem secara berkelompok pada siklus I. Hasil nilai tes kemampuan analisis siswa pada siklus I mencapai 66,98 dengan kriteria sedang. Aspek analisis yang terkategori sedang menunjukan siswa mampu mengidentifikasi informasi utuh menjadi bagianbagian kecil, dan menemukan hubungan antarkomponen yang saling terkait. Pada siklus II siswa membahas aliran energi yang terjadi dalam ekosistem yang meliputi: rantai makanan, jaringjaring makanan, serta piramida ekologi. Siswa sudah mulai dapat menganalisis data pengamatan yang didapat dari hasil diskusi secara kelompok.

Hasil nilai tes pada siklus II mencapai 80,52 dengan kriteria tinggi. Aspek analisis yang terkategori tinggi menunjukan siswa mampu menemukan adanya bias informasi berdasarkan pada sudut pandang yang berbeda dari suatu bentuk komunikasi.

Peningkatan terjadi karena siswa terlatih menggunakan kemampuan analisis dalam proses identifikasi masalah dengan cara fluent thinking skill, yaitu kegiatan yang secara sistematis melatih siswa berpikir mengenai topik yang dipelajari dengan membimbing siswa untuk menyusun berbagai pertanyaan (Robbins, 2011). Proses identifikasi merupakan subskill dari kemampuan analisis (Zane, 2013) sehingga dengan membiasakan siswa melakukan identifikasi masalah dapat meningkatkan kemampuan analisis. Kemampuan menganalisis diperlukan untuk menghubungkan pecahan-pecahan dari bagian sebuah informasi sehingga dapat menentukan maksud dari informasi tersebut. Setelah menganalisis informasi, aktivitas selanjutnya adalah mengevaluasi.

Kemampuan mengevaluasi diperlukan setelah mengetahui hubungan dari pecahan dari suatu informasi, yaitu untuk mengetahui apakah informasi tersebut dapat dipercaya atau tidak dengan mencari validitas informasi melalui pengalaman dan opini seseorang. Siswa dilatihkan kemampuan mengevaluasi pada sintaks hypothesis testing dan regulation dari model discovery learning. Kegiatan mengevaluasi terlihat dari aktifitas siswa memeriksa kesesuaian bagianbagian dari suatu informasi secara berkelompok. Siswa menguji kesesuaian kesimpulan dengan 
hipotesis dan hasil hasil eksperimen yang diperoleh. Pada siklus I siswa mengevaluasi mengenai komponen-komponen penyusun ekosistem yang ada di lokasi sekolah. Siswa menggunakan kemampuan berpikir evaluasi bersama dengan berkelompok.

Hasil tes kemampuan mengevaluasi pada siklus I mencapai 64,17 dengan kriteria sedang. Aspek mengevaluasi yang terkategori sedang menunjukan siswa mampu menemukan inkonsistensi dari suatu informasi, membuat keputusan berdasarkan kriteria yang telah ditetapkan, dan mengkritisi keputusan yang telah dibuat. Selanjutnya pada siklus II kegiatan mengevaluasi membahas aliran energi yang terjadi dalam ekosistem yang meliputi: rantai makanan, jaring-jaring makanan, serta piramida ekologi yang terjadi di dalam suatu ekosistem.

Hasil nilai tes pada siklus II mencapai 73,96 dengan kriteria sedang. Aspek mengevaluasi yang terkategori sedang menunjukan siswa mampu menemukan inkonsistensi dari suatu informasi, membuat keputusan berdasarkan kriteria yang telah ditetapkan, dan mengkritisi keputusan yang telah dibuat. Meskipun pada siklus I mengalami peningkatan sebesar 18,34 dari pratindakan dan pada siklus II mengalami peningkatan sebesar 28,13 dari pratindakan, tetapi jika dilihat dari perbandingan antara siklus I dan II mengalami penurunan. Hal ini dapat dilihat dari nilai kategori dari aspek mengevaluasi, yakni pada kategori soal mengkritik (critiquing) yang turun sebesar 3,13. Hal ini dikarenakan pada aspek mengevaluasi yakni, kategori mengkritik (critiquing) merupakan salah satu kemampuan yang dianggap kompleks. Seseorang perlu mengerti teori terlebih dahulu sebelum melakukan penilaian, sehingga memerlukan waktu yang lebih lama untuk melihat peningkatan yang lebih signifikan.

Penurunan pada aspek mengevaluasi juga dapat disebabkan dari keterlaksanaan pada sintaks regulation yakni, pada saat guru mereview hasil belajar siswa. Guru memberikan penjelasan materi yang terlalu singkat dan cepat sebelum siswa dapat menilai informasi tersebut. Pada lembar observasi keterlaksanaan sintaks discovery learning pada siklus II, guru mereview pembelajaran terlalu cepat. Siswa tidak dapat terlebih dahulu memproses hasil diskusi secara kelompok dengan teori atau informasi. Selain dikarenakan faktor-faktor yang telah dijelaskan, diduga capaian kemampuan mengevaluasi untuk kategori soal mengkritik (critiquing) siswa di kelas X IPA SMA tersebut disebabkan oleh kemampuan adaptasi dari dalam diri siswa di kelas yang masih kurang, sehingga mengakibatkan beberapa siswa tidak banyak terlibat dalam diskusi dan tanya jawab kelompok, sehingga jarang sekali mengajukan pertanyaan. Beberapa siswa lain cenderung memilih untuk menuliskan hasil diskusi dibanding mengajukan pertanyaan dan berpartisipasi aktif dalam diskusi karena merasa kontribusinya tidak mampu memberikan banyak pengaruh terhadap penyelesaian masalah kelompok. Komunikasi dalam kelompok menyediakan kesempatan bagi siswa untuk merefleksi penjelasan mereka dan memperkirakan implikasi lebih lanjut dari hasil temuan mereka. Hubungan antara pertanyaan yang diajukan dengan penjelasan yang didapat setelah melaksanakan kegiatan pengujian hipotesis dapat diketahui dengan baik melalui komunikasi.

Ciri yang terlihat dari kemampuan berpikir mencipta, yakni adanya kegiatan yang mengarah dalam menyusun sesuatu dari yang telah dipelajari menjadikan suatu gagasan yang baru atau yang belum pernah dilakukan melalui merencanakan berbagai solusi, kemudian merancang langkah yang sesuai sehingga tercipta suatu produk baru itu. Siswa dilatihkan kemampuan mencipta pada Sintaks hypothesis generation dan hypothesis testing dari model discovery learning. Kegiatan mencipta terlihat dari aktifitas siswa menyusun hipotesis atau jawaban sementara, kemudian secara berkelompok siswa menyusun ide untuk menyelesaikan masalah siswa yang telah disepakati. Pada siklus I ide siswa untuk memecahkan masalah dari hipotesis, yakni dengan melakukan pengamatan komponen-komponen penyusun ekosistem di lokasi sekolah.

Hasil nilai tes kemampuan mencipta pada siklus I mencapai 68,49 dengan kriteria sedang. Aspek mencipta yang terkategori sedang menunjukan siswa mampu membuat hipotesis dan mendeskripsikan rencana solusi masalah dan merancang cara pengerjaan dengan memadukan bagian-bagian dari langkah pengerjaan manjadi kesatuan yang baru dalam rangka pembuktian untuk hipotesis yang telah ditetapkan. Selanjutnya pada siklus II kegiatan mencipta membahas aliran energi yang terjadi dalam ekosistem yang meliputi: rantai makanan, jaring-jaring makanan, serta piramida ekologi.

Hasil nilai tes pada siklus II mencapai 76,35 dengan kriteria tinggi. Aspek mencipta yang terkategori tinggi menunjukan siswa mampu membuat hipotesis dan merencanakan solusi dengan mengorganisasikan unsur-unsur atau bagian-bagian menjadi struktur baru yang belum pernah ada sebelumnya (orisinil) dan kreatif. Meskipun pada siklus I mengalami peningkatan sebesar 18,18 dari pratindakan dan siklus II mengalami peningkatan sebesar 26,04 dari pratindakan, tetapi jika dilihat dari perbandingan antara siklus I dan II mengalami penurunan. Hal ini dapat dilihat dari kategori mencipta, yakni kategori soal merencanakan (planning) yang turun sebesar 1,88 . 
Data kemampuan berpikir tingkat tinggi siswa kelas X IPA SMA mengalami fluktuasi pada siklus I dan II. Penurunan hasil tes kemampuan berpikir tingkat tinggi pada beberapa aspek terjadi dikarenakan siswa yang kurang terlibat aktif pada masing-masing tahap pembelajaran Biologi. Siswa mengerjakan aktivitas lain seperti mengerjakan tugas selain Biologi dan membicarakan hal di luar konteks pelajaran. Setiap sintaks dari model discovery learning mengakomodasi siswa untuk memberdayakan masing-masing aspek kemampuan berpikir tingkat tinggi. Kurangnya keterlibatan dalam setiap sintaks discovery learning membuat siswa kurang maksimal dalam melatihkan setiap aspek kemampuan berpikir analyzing, evaluating, dan creating sehingga capaian kemampuan berpikir tingkat tinggi yang diperoleh menurun.

Secara keseluruhan capaian nilai aspek kemampuan berpikir tingkat tinggi siswa pada siklus I dan II sudah meningkat dibandingkan dengan pratindakan karena setiap sintaks dari model discovery learning dalam memberdayakan kemampuan berpikir tingkat tinggi siswa terlatih dengan baik. Peningkatan pada siklus II telah memenuhi target penelitian $\geq 25$ dikarenakan siswa sudah mulai terbiasa dan memahami cara-cara menyelesaikan LKS, peningkatan bimbingan yang dilaksanakan oleh guru dan penambahan sumber referensi serta media video yang memberikan gambaran yang lebih luas kepada siswa.

Berdasarkan hasil wawancara dengan guru dan siswa menyatakan bahwa siswa lebih memahami dan lebih leluasa serta antusias dalam menyampaikan pendapat maupun mengajukan pertanyaan mengenai materi pembelajaran sehingga pembelajaran menjadi tidak membosankan, hasil wawancara dengan guru menjelaskan bahwa pembelajaran siklus II tidak mengalami kendala karena telah dilakukan evaluasi pada siklus I, selain itu siswa juga telah mampu menyesuaikan diri sehingga pembelajaran menjadi lebih lancar dan aktif.

\section{KESIMPULAN}

Berdasarkan hasil penelitian dapat disimpulkan bahwa ada peningkatan kemampuan berpikir tingkat tinggi siswa sebesar $\geq 25$ melalui penerapan model discovery learning pada siswa kelas X IPA SMA. Model Discovery Learning memiliki sintaks pembelajaran yang dapat meningkatkan kemampuan berpikir tingkat tinggi siswa.

Hasil penelitian ini secara teoritis dapat dijadikan sebagai referensi dalam pengembangan penelitian tindakan kelas lebih lanjut dalam rangka meningkatkan kemampuan berpikir tingkat tinggi siswa. Secara praktis dapat diterapkan pada proses pembelajaran materi ekosistem untuk meningkatkan kemampuan berpikir tingkat tinggi siswa serta sebagai alternatif dalam memilih sistem pembelajaran untuk meningkatkan kualitas pembelajaran biologi di kelas.

\section{UCAPAN TERIMAKASIH}

Peneliti menyampaikan terima kasih pada seluruh pihak yang membantu terselesaikannya penelitian ini hingga tahap penyusunan laporan.

\section{DAFTAR PUSTAKA}

Ahmadi, R. (2014). Pengantar Pendidikan. Yogjakarta: Ar-Ruzz Media.

Akinbobola,A.O. \& Afolabi,F. (2010). Constructivist Pratices Through Guided Discovery Approach: The Effect on Student Cognitive Achievement in Nigerian Senior Secondary School Physics. Eurasian Journal of Physics and Chemistry Education.Vol 2 (1) : $16-25$.

Akınoğlu, O., \& Tandogan, R. O. (2007). The Effects of Problem-Based Active Learning in Science Education on Students' Academic Achievement, Attitude and Concept Learning. Eurasia Journal of Mathematics, Science \& Technology Education, 3(1), 71-81.

Anderson,L.W., \& Karthwohl, D. R. (Eds). (2010). Kerangka Landasan untuk Pembelajaran, Pengajaran, dan Asesmen. Yogyakarta: Pustaka Pelajar.

Arifin, Z. (2009). Evaluasi Pembelajaran. Bandung: PT Remaja Rosdakarya.

Art-in, S. (2012). Development of teacher's Learning Management emphasizing on Analytical Thinking in Thailand. Social and Behavioral Science , 33393344.

Barak,M., Ben C,D., \& Zoller,U. (2007). Purposely Teaching for The Promotion of Higher Order Thingking Skills : A Case of Critical Thingking. Research Science Education,37, 353-369.

Burke, Lynsey. A., \& Williams, J. M. (2012). The Impact of a thinking Skills Intervention on Children's Concepts of Intelegence. Journal Thinking Skill and Creativity, (7) 145-152.

Burns, D.E., Leppien, J., Omdal, S., Gubbins, E. J., Muller, L\& Vahidi,S. (2006). Teachers' Guide for the Explicit Teaching of Thinking Skills. University of Connecticut: The National Research Center on the Gifted and Talented.

Chatib, M. (2012). Orangtuanya manusia:Melejitkan Potensi dan Kecerdasan dengan Menghargai Fitrah Setiap Anak. Bandung: Kaifa.

Deluty, E. W. (2010). Asking Questions:Cultivating the Habit of Inquiry. The Nea Higher Education Journal, 135-138.

Heong, Y. M., Othman, W., Yunos, J., Kiong, T., Razali., \& Mohamad, M. (2011). The Level of Marzano Higher Order Thinking Skills among Technical Education Students. International Journal of Social Science and Humanity, Vol. 1, No. 2. 
Heong, Y. M., Othman, W., Yunos, J., Kiong, T., Razali., \& Mohamad, M. (2012). The needs analysis of learning higher order thinking skills for generating ideas. Journal Social and Behavioral Sciences 59, $197-203$.

Greenhill, V. (2010). 21st Century Knowledge and skill in Educator Preparation. Partnership for 21st Century Skill.

Klahr, D., \& Nigam, M. (2004). The Equivalence of Learning Paths in Early Science Instruction: Effects of Direct Instruction and Discovery Learning. Psycological Science, XV (10), 661-667.

Kemmis, S., \& McTaggart, R. (2005). Participatory Action Research: Communicative Action and the Public Sphere. In I. K. Denzin, Handbook of Qualitative Research (pp. 559-600). California: Sage.

Kowalski, F. V., \& Kowalski, S. E. (2012, October). Enhancing Curiosity Using Interactive Simulations Combined With Real-Time Formative Assessment Facilitated by Open-Format Questions on Tablet Computers. Frontiers in Education Conference (FIE) , 1-6.

Litman. (2005). Curiosity and the Pleasure of Learning: Wanting and Liking New Information. Journal of Cognition and Emotion.

Ramos, J, L, S., Dolipas, B, B,. \& Villamor, Brenda, B. (2013). Higher Order thinking Skill and Academic Performance in Physics of Collage Students: Regression Analysis. International Journal of Innovative Interdisciplinary Research. issue 4, 48-60.

Robbins,J.K. (2011).Problem Solving, Reasoning and Analytical Thinking in a Classroom Environment. Journal the Behavior Analyst Today. Vol 12 (1).

Salter, N. P., \& Connely, M. R. (2015). Structured and Unstructured Discussion Forums as Tools for Student Engagement. Journal Computers in Human Behavior (46) $18-25$.

Sitthipon, A, I. (2012). Development of Teacher's Learning Management Rmphasizing on Analitical Thinking in Thailand. Journal Social and Behavioral Sciences 46, 3339-3344.

Sumantri, M., \& Permana, J. (2001). Strategi Belajar Mengajar. Bandung: Bumi Aksara.

Yaumi, Muhammad. (2013). Prinsip-Prinsip Pembelajaran. Jakarta: Kencana Pranada.

Yunginger, R.(2008). Deskripsi tentang Kemandirian Siswa pada Mata Pelajaran Fisika. Jurnal Penelitian dan Pendidikan, 5(1), 64-69.

Veermans, K. (2003). Intelligent Support for Discovery Learning. Netherland: Twente University Press.

Walsh, J. A., \& Sattes, B. D. (2011). Thinking Through Quality Questioning: Deepening Student Engagement. United States of America.

Zane, T. W. (2013). Implementing Critical Thinking with Signature Assignments. Spring: Salt Lake Community College. 